\title{
The Radiolaria of the Herefordshire Konservat-Lagerstätte (Silurian), England
}

\author{
DAVID J. SIVETER ${ }^{1}$, JONATHAN C. AITCHISON ${ }^{2}$, DEREK J. SIVETER ${ }^{3} \&$ MARK D. SUTTON $^{4}$ \\ ${ }^{1}$ Department of Geology, University of Leicester, University Road, Leicester LE1 7RH, UK (e-mail: djs@leicester.ac.uk) \\ ${ }^{2}$ Department of Earth Sciences, University of Hong Kong, Pokfulam Road, Hong Kong SAR, China (e-mail: jona@hku.hk) \\ ${ }^{3}$ Geological Collections, University Museum of Natural History \& Department of Earth Sciences, University of Oxford, Oxford OX1 3PW, UK \\ (e-mail: derek.siveter@earth.ox.ac.uk) \\ ${ }^{4}$ Department of Earth Sciences and Engineering, Imperial College London, South Kensington Campus, London SW7 2BP, UK
} (e-mail: m.sutton@imperial.ac.uk)

\begin{abstract}
Concretions of the Wenlock Series Herefordshire Konservat-Lagerstätte of the Welsh Borderland have yielded one of the few recorded Silurian radiolarian faunas world-wide and the only one known from the Silurian of Britain. The low diversity radiolarian fauna consists of new forms of Inaniguttidae (Inanihella sagena sp. nov. and Inanihella sp.), Haplentactiniidae (Haplentactinia armista sp. nov.) and a previously reported form of Secuicollactidae (Secuicollacta hexatinia (Won et al., 2002)). The fauna has affinities with Silurian radiolarian assemblages of the Urals, the Canadian Arctic and Alaska. Stratigraphically the Herefordshire fauna appears transitional between established Silurian radiolarian biozones. J. Micropalaeontol. 26(1): 87-95, April 2007.
\end{abstract}

KEYWORDS: Radiolaria, Konservat-Lagerstätte, Wenlock Series, Silurian, England

\section{INTRODUCTION}

Radiolaria are Cambrian to Recent marine Protozoa represented in the stratigraphic record by their siliceous tests (Anderson, 1983). The group has importance in biostratigraphical and tectonic studies (e.g. Aitchison \& Murchey, 1992; Noble \& Aitchison, 2000). Radiolarian faunas from the Lower Palaeozoic are quite rare (e.g. see Noble \& Aitchison, 1995, 2000) and relatively little studied. The discovery of radiolarians in the Silurian of Britain was based on material from concretions from Herefordshire in the Welsh Borderland, where the tests occur in association with a Konservat-Lagerstätte of Wenlock age (Briggs et al., 1996).

In addition to the normal shelly fauna the Herefordshire Konservat-Lagerstätte yields numerous small marine invertebrates with soft anatomy preserved in three dimensions. They include a stem group chelicerate (Orr et al., 2000a; Sutton et al., 2002), a vermiform aplacophoran-like mollusc (Sutton et al., 2001a, b, 2004), a polychaete worm (Sutton et al., 2001c), two myodocope ostracod species (Siveter et al., 2003, 2007), a phyllocarid (Briggs et al., 2004), a pycnogonid (Siveter et al., 2004), a barnacle (Briggs et al., 2005), a rhynchonelliformean brachiopod (Sutton et al., 2005a), a stem-group asteroid (Sutton et al., 2005b), a platyceratid gastropod (Sutton et al., 2006) and various undescribed sponges, orthoconic nautiloids, arthropods, echinoderms, graptolites and enigmatic forms of uncertain affinity. The fossils are exquisitely preserved as calcite infills within the concretions (Orr et al., 2000b). The morphology of each species is recovered and elucidated as a series of 'virtual fossils' using the methods developed by Sutton et al. (2001d, 2002). Acid digestion of thin-section off-cuts from the concretions has yielded a microfauna of mostly radiolarians, together with a few ostracod valves and conodont elements. Preservational aspects of the radiolarians, and the attendant implications for the taphonomy of the biota, have been addressed (Orr et al., 2002). This paper describes the radiolarian fauna and assesses its biostratigraphic and palaeozoogeographical significance.

\section{METHODS AND MATERIAL}

The radiolarian-bearing concretions are up to about $20 \mathrm{~cm}$ across, spherical to subspherical and composed mostly of calcium carbonate and clay minerals. The radiolarians are visible as randomly scattered specimens on the surfaces of concretions that have been broken using mechanical methods. Most of the radiolarians were recovered using about $4 \%$ acetic acid, followed by concentration in bromoform $\left(\mathrm{CHBr}_{3}\right)$ and then sieving with the $63 \mu \mathrm{m}$ fraction collected and dry picked. The off-cuts from about 40 concretions were processed, yielding a few hundred poorly preserved to well-preserved tests in generally low abundances of 2-25 tests per $500 \mathrm{~g}$ sample.

The radiolarians recovered show an unusual preservation (Orr et al., 2002). Tests are preserved replicated in ankerite and clay minerals and occur either isolated or enclosed (c. $75 \%$ of the material) in spherical 'cocoons'. The cocoons are composed of quartz, kaolinite, pyrite or most commonly ankerite. The latter is a product of secondary dolomitization of the sparry calcite that was precipitated in the space originally occupied by the cytoplasm of the radiolarian (Orr et al., 2002).

The specimens were coated with gold prior to study using scanning electron microscopy. The figured material is deposited at the University Museum of Natural History, Oxford, nos. OUM C29536, C.29542, C.29594 to C.29598.

\section{GEOLOGICAL SETTING}

The radiolarian-bearing concretions occur randomly scattered within a fine-grained, weathered volcanic ash that has a maximum thickness of $1 \mathrm{~m}$ and is traceable laterally for approximately $40 \mathrm{~m}$. The ash lies near the local base of several metres of 
calcareous shales. Palynological data obtained from processing the shales (G. Mullens, pers. comm., 2000), together with macrofossil evidence from local Wenlock strata, especially graptolites and brachiopods, infer a late Sheinwoodian to early Homerian (=approximately Cyrtograptus ellesae to Cyrtograptus lundgreni biozones), Wenlock Series age for the ash.

The ash and carbonate-rich muds accumulated on the outer margin of the eastern shelf of the Lower Palaeozoic Welsh depositional basin (see Bassett, 1974; Bassett et al., 1992; Aldridge et al., 2000), which was part of the microcontinent of Avalonia. In Wenlock times Avalonia lay at the southern margin of the remnant Iapetus Ocean in subtropical southerly latitudes, in proximity to the palaeocontinents of Laurentia and Baltica (Pickering \& Smith, 1995; Fortey \& Cocks, 2003). The calcareous shales yield the low diversity Visbyella brachiopod community (Hurst et al., 1978), which is characteristic of sites near the outer limit of the shelly benthos during the Wenlock and probably reflects prevailing water depths of about 150-200 m (Brett et al., 1993). Silurian radiolarian faunas world-wide, range from shallow shelf to abyssal oceanic settings.

\section{STRATIGRAPHIC SIGNIFICANCE}

The development of biostratigraphic schemes based on Silurian Radiolaria is still in its infancy. Silurian radiolarians are known from North America, Asia and Europe, in Llandovery to Přídolí strata, but described faunas are rare and their biostratigraphic potential has yet to be realized fully. Silurian radiolarians have been recorded from Germany (Stürmer, 1952; Noble et al., 1998), the southern Urals part of Russia and Kazakhstan (Nazarov, 1975, 1988; Nazarov \& Popov, 1980; Nazarov \& Ormiston, 1984, 1993; Amon et al., 1995), the Canadian Arctic (Goodbody, 1986; Renz, 1988; MacDonald, 1998, 1999, 2003, 2004, 2006a, b; Jones \& Noble, 2006), Japan (Furutani, 1990; Wakamatsu et al., 1990; Aitchison et al., 1996; Umeda, 1997, 1998a, b, c; Kurihara \& Sashida, 1998), Australia (Aitchison, 1991), Poland (Gorka, 1994), China (Li, 1994), Texas (Noble, 1994), Nevada (Noble et al., 1997, 1998), Sweden (Maletz \& Reich, 1997; Noble \& Maletz, 2000; Umeda \& Suzuki, 2005) and Alaska (Won et al., 2002). Illustrations of the radiolarian faunas of purported Silurian age from southern France (Rüst, 1892) indicate they are more likely to be from Lower Carboniferous strata.

Radiolarian-bearing deposits of Wenlock age occur in the Canadian Arctic, with earlier studies describing the Palaeoscenidae and Ceratoikiscidae that dominate the faunas (Goodbody, 1986; Renz, 1988; MacDonald, 2003, 2004), whilst the secuicollactids and entactiniids are a minor component of these faunas and described in more recent work (MacDonald, 2003, 2006a; Jones \& Noble, 2006). Some radiolarians described from China, Japan and the southern Urals and the early faunas from Texas (references as above) may also be of Wenlock age but, with the exception of samples from Japan for which SHRIMP data for pyroclastic zircons in radiolarian-bearing water-lain tuffs are available (Aitchison et al., 1996), independent stratigraphic age control is not available.

In the lower Palaeozoic radiolarian biozonation proposed by Noble \& Aitchison (2000), the base of the Silurian Long-spined inaniguttid Biozone 2 is defined by the Last Appearance Datum
(LAD) of members of the Haplentactiniinae such as Haplotaeniatum Nazarov \& Ormiston, 1993 as well as that of Gyrosphaera Noble \& Maletz, 2000; forms which have multiple spiraliform or concentric shell layers (Fig. 1; note that the range of Gyrosphaera was drawn slightly too high in Noble \& Aitchison, 2000, fig. 1, as its LAD should correspond with that of Haplotaeniatum). Such forms are common in late Llandovery (mid-Telychian Spirograptus turriculatus Biozone) faunas from Sweden but are absent from the Herefordshire fauna, possibly indicating that the LAD of such forms lies below the Sheinwoodian/Homerian stage boundary. The First Appearance Datum (FAD) of Ceratoikiscum Deflandre, 1953 defines the base of Long-spined inaniguttid Biozone 3 (Noble \& Aitchison, 2000), in which the Inanihella tarangulica Nazarov \& Ormiston, 1984 Group occurs. Ceratoikiscum is not present in the Herefordshire fauna but inanihellid specimens are relatively plentiful. This could be taken to indicate that the Herefordshire fauna contains radiolarians from a stratigraphic interval intermediate between the ranges of Long-spined inaniguttid Biozones 2 and 3 of Noble \& Aitchison (2000). Alternatively, it is possible that the absence of Ceratoikiscum in the Herefordshire fauna is related to preservational factors. As ceratoikiscids are known from the Sheinwoodian of the Canadian Arctic (Renz, 1988), it is suggested that Noble \& Aitchison (2000) may have drawn this boundary a little too high. The authors do not have series of samples that span a longer stratigraphic interval so are unable to clarify this issue further. It is noted that even where wellpreserved material is available from sections of correlative age, such as the Cape Phillips Formation in the Canadian Arctic, recent work has not yet led to a unique and unambiguous interpretation of biozonation for this interval (MacDonald, 2006b, cf. Jones \& Noble, 2006).

\section{PALAEOZOOGEOGRAPHICAL AFFINITIES}

The Herefordshire radiolarian fauna has only limited faunal ties with other regions. It has affinities at generic level with material described (Nazarov, 1988) from the upper part of the Sakmarskaya Suite (Wenlock?-Ludlow) of northwestern Mugodzhar in the southern Urals part of Kazakhstan. One rotaspherid species known from the late Aeronian to early Telychian, Llandovery Series of the Road River Formation, Tatonduk River area, east central Alaska (Won et al., 2002) also occurs in the Herefordshire fauna.

\section{SYSTEMATIC PALAEONTOLOGY \\ Class Actinopoda Calkins, 1909 \\ Subclass Radiolaria Müller, 1858 \\ Order Polycystida, Ehrenberg, 1838 \\ Suborder Spumellariina Ehrenberg, 1875 \\ Family Inaniguttidae Nazarov \& Ormiston, 1984 \\ (emend Noble, 1994) \\ Genus Inanihella Nazarov \& Ormiston, 1984}

Type species. Helioentactinia? bakanasensis Nazarov, 1975, Ordovician of central Kazakhstan.

Remarks. In addition to the specimens assigned herein to Inanihella at least two other, previously figured specimens 


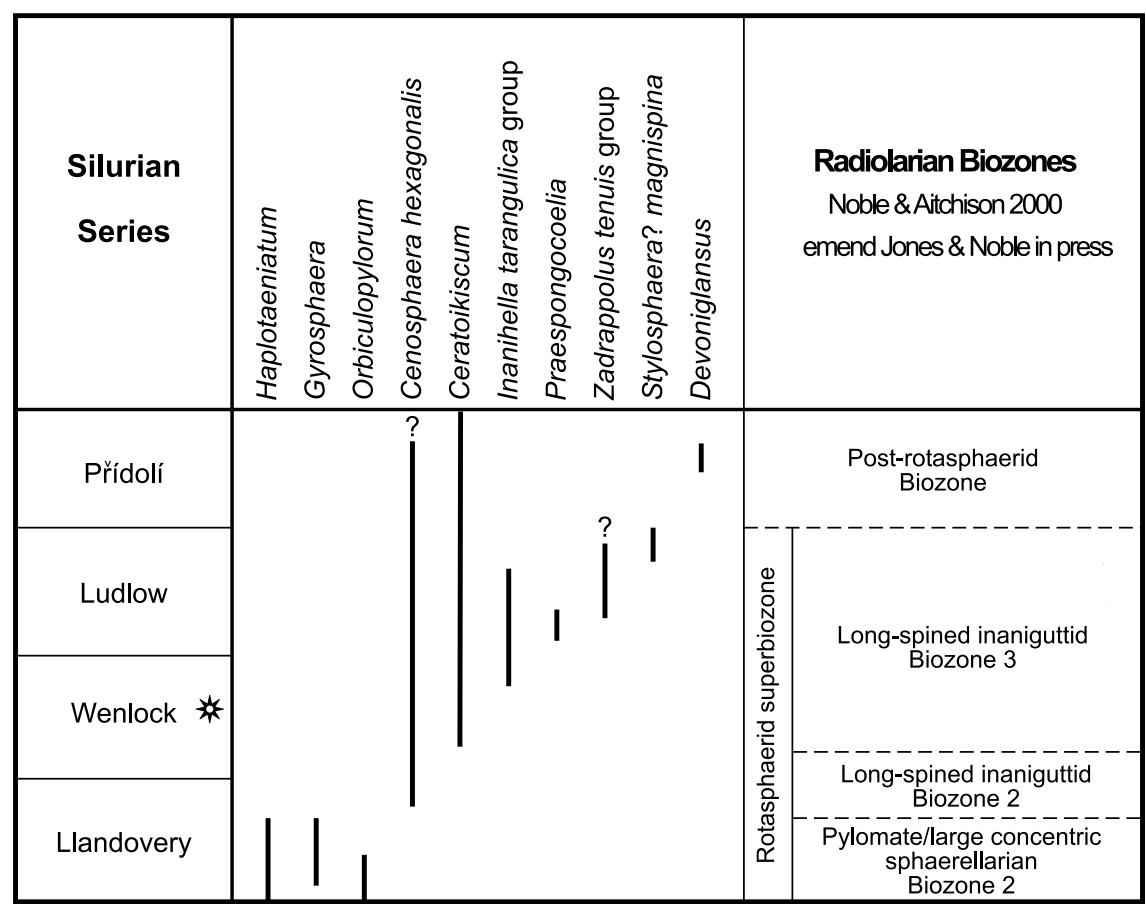

Fig. 1. Stratigraphic occurrence of key Silurian radiolarian taxa and the radiolarian biozones of Noble \& Aitchison (2000), as revised by Jones \& Noble (in press). The icon denotes the stratigraphic position of the radiolarian fauna of the Herefordshire Konservat-Lagerstätte.

from the Herefordshire Konservat-Lagerstätte may also be congeneric (Orr et al., 2002: pl. 1, fig. 9, OUM C.29537; pl. 2, figs 1, 4, OUM C.29538). These specimens are mostly hidden within 'cocoons' and more detailed identification is not possible.

\section{Inanihella sagena $\mathrm{sp}$. nov.}

(P1. 1, figs 1-7)

2002 unnamed spumellarian specimens (OUM C.29502, C.29534, C.29535, C.29536) Orr et al.: pl. 1, figs 1-8.

Derivation of name. Latin, sagena, a fish-net; alluding to the porous shells.

Diagnosis. Large Inanihella species, $>200 \mu \mathrm{m}$ diameter, with two cortical shells, secondary spines and relatively few main spines.

Holotype. University Museum of Natural History, Oxford, OUM C.29594; Plate 1, figs 1-4. Late Sheinwoodian to early Homerian, Wenlock Series, Herefordshire.

Material. At least ten specimens.

Description. The two cortical shells are concentric, irregularly porous and close together (see Pl. 1, fig. 6 where a finer inner cortical shell can be seen $<50 \mu \mathrm{m}$ below the pores of the outer cortical shell on specimen OUM C. 29595). They are interconnected by numerous small rods that do not extend beyond the shells. Numerous (6-20) long, rod-like cylindrical, non-tapering main spines are connected with solid rays of the internal framework to the inner cortical shell. They are buttressed at the outer-most cortical shell and their diameter is considerably less towards the medullary shell. Numerous secondary spines emanate from nodes between pores on the outer-most cortical shell.

Distribution. Known only from the type locality.

Remarks. I. sagena is similar to several inanihellids described from the upper part of the Sakmarskaya Suite (Wenlock?Ludlow) of northwestern Mugodzhar, southern Urals, Kazakhstan (Nazarov, 1988; described in English in Nazarov \& Ormiston, 1993) in having two irregularly porous cortical shells. However, I. sagena differs in having considerably fewer main spines than Inanihella permeata Nazarov \& Ormiston, 1993, I. leniuncula Nazarov \& Ormiston, 1993 and I. macrocantha (Rüst, 1892) of Nazarov (1988) and it also has secondary spines.

Nazarov (1988) regarded some of his material as conspecific with Acanthosphaera macrocantha Rüst, 1892 from France. However, the French taxon has well-developed pores and appears to have a single cortical shell, whereas the material from Kazakhstan is irregularly porous and has a double cortical shell. The entire assemblage described from supposedly Silurian rocks of Cabrière in France exhibits greater similarity to Lower Carboniferous rather than Silurian forms, and it seems likely that the material that Nazarov (1988) assigned to I. macrocantha is a different species. Indeed, Noble (1994) reassigned this taxon to Oriundogutta Nazarov, 1988. 


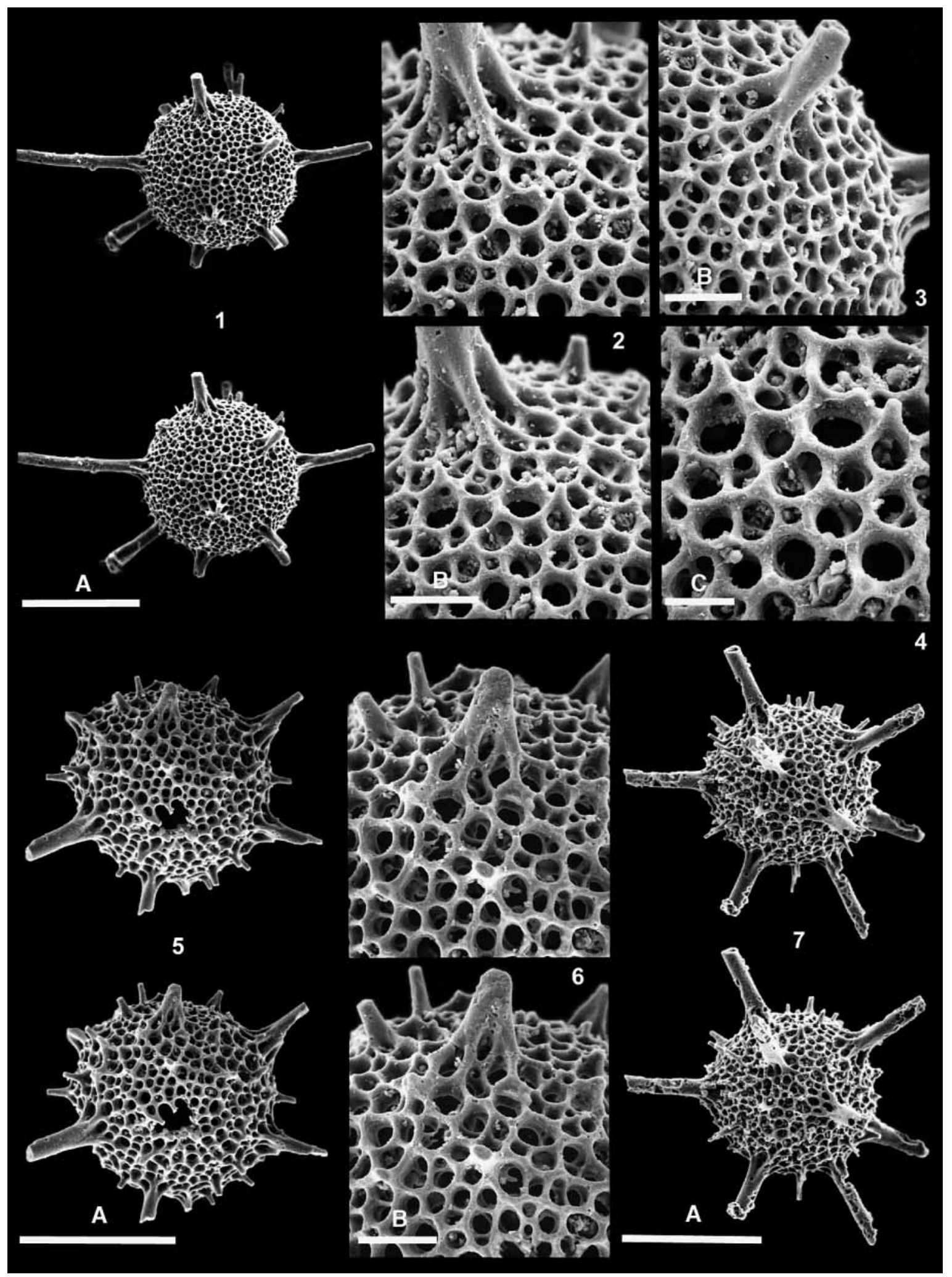

Explanation of Plate 1.

All of the specimens (University Museum of Natural History, Oxford) are from the Wenlock Series, Silurian, Herefordshire, England. Figs 1, 2, 5-7 are stereo-pairs. figs 1-7. Inanihella sagena sp. nov.: 1-4, holotype, OUM C.29594 - 1, complete specimen, $\times 75$, 2-4, details of lattice and spines, $\times 300, \times 280, \times 510 ; \mathbf{5}-\mathbf{6}$, OUM C. $29595-\mathbf{5}$, complete specimen, $\times 100, \mathbf{6}$, details of lattice and spines, $\times 250 ; \mathbf{7}$, OUM C.29536, complete specimen, $\times 90$. Scales: A, $250 \mu \mathrm{m} ; \mathrm{B}, 50 \mu \mathrm{m} ; \mathrm{C}, 25 \mu \mathrm{m}$. 
Silurian Radiolaria of England

\section{Inanihella $\mathrm{sp}$}

(Pl. 2, figs 1-5)

2002 unnamed spumellarian specimens (OUM C.29540, OUM C.29541, OUM C.29542) Orr et al.: pl. 2, figs 5-8.

Material. About ten specimens

Description. Large, robust, porous inner cortical shell, $>250 \mu \mathrm{m}$ diameter, separated from an additional gossamer outer cortical shell by approximately $50 \mu \mathrm{m}$. The outer cortical shell is extremely fragile and may be openly latticed. The shells are concentric and are interconnected by numerous small rods that do not extend beyond the shells. About six long, rod-like cylindrical, non-tapering main spines are buttressed onto the innermost cortical shell. The outer cortical shell lies beyond the buttresses. Thin solid rays emanating from the main spines continue inside the internal framework.

Distribution. Known only from the Herefordshire KonservatLagerstätte.

Remarks. Description of this form is limited by the fragmentary preservation of the specimens. Vestiges of several extremely fragile gossamer outer cortical shells, in addition to those noted in the description, are observable in several specimens within surrounding spherical 'cocoons' (P1. 2, figs 2, 3, 5), but it has proved impossible to isolate such tests intact. Full details of the original structure remain unknown.

Order Entactinaria, Kozur \& Mostler, 1982

Family Haplentactiniidae Nazarov in Nazarov \& Popov, 1980 Subfamily Haplentactiniinae Nazarov in Nazarov \& Popov, 1980 Genus Haplentactinia Foreman, 1963

Type species. Haplentactinia rhinophyusa Foreman, 1963, Upper Devonian Huron Shale, Ohio.

\section{Haplentactinia armista sp. nov.}

(Pl. 2, fig. 7)

Derivation of name. Latin arma, weapons, and suffix ista, signifying an agent; alluding to the appearance of the spines.

Diagnosis. Haplentactinia with small, spherical, pseudo-spongy cortical shell. Six massive, rod-like cylindrical and gradually tapering main spines that meet at a point-centred spicule; no secondary spines. No medullary shell visible.

Holotype. University Museum of Natural History, Oxford, OUM C.29598; Plate 2, fig. 7. Late Sheinwoodian to early Homerian, Wenlock Series, Herefordshire.

Material. About ten specimens.

Description. Specimens have a well-developed spherical pseudospongy cortical shell approximately $90 \mu \mathrm{m}$ in diameter. Six massive rod-like spines are well developed and taper gently. The maximum length of these spines and the nature of their distal terminations were not observed on specimens, all of which are broken. Main spines meet at a point-centred spicule. No secondary spines were observed on any specimen.

Distribution. Known only from the type locality.

Remarks. $H$. armista differs from $H$. silurica Nazarov \& Ormiston, 1993 from the Lower Silurian Sakmarskaya Suite of the southern Urals in that the apophyses that join to form the cortical shell are notably less coarse (thinner).

Order Archaeospicularia Dumitrica, Caridroit \& DeWever, 2000

Superfamily Secuicollactacea Nazarov \& Ormiston, 1984 (synonym: Rotasphaeracea Noble, 1994)

Family Secuicollactidae Nazarov \& Ormiston, 1984 (synonym: Family Rotasphaeridae Noble, 1994; emend Noble \& Maletz, 2000; Won et al., 2002)

Discussion. See Dumitrica et al. (2000), Noble \& Maletz (2000) and Won et al. (2002) for discussion of higher-level taxonomic assignments within the Order Archaeospicularia.

Genus Secuicollacta Nazarov \& Ormiston, 1984 (emend MacDonald, 1998)

(synonym: Genus Parasecuicollacta Won, Blodgett \& Nestor, 2002 (see Jones \& Noble, 2006))

Type species. Secuicollacta cassa Nazarov \& Ormiston, 1984, Silurian Wenlock-Ludlow series, Tarangul River, northern Mugodzhar, southern Urals, Kazakhstan.

Secuicollacta hexactinia (Won, Blodgett \& Nestor, 2002) (P1. 2, fig. 6)

2002 Parasecuicollacta hexactinia Won et al.: 955, fig. 3: 7-11.

Material. Five specimens.

Description. Single, very small spherical shell approximately 50-60 $\mu \mathrm{m}$ diameter. Six short main spines approximately half the diameter of the shell and strongly tapering. Two spines are polar and better developed that the others which are arranged equatorially. The shell is irregularly reticulated and ragged.

Distribution. Known from the Road River Formation, late Aeronian to early Telychian, Llandovery Series, Tatonduk River area, east central Alaska, as well as the late Sheinwoodian to early Homerian, Wenlock Series of Herefordshire.

Remarks. The Herefordshire specimens have a dense ragged lattice and are closely similar to S. hexactinia (Won et al., 2002). Although the two largest spines are polar and similar to those observed in S. bipola (Won et al., 2002), the presence of four additional spines suggests assignment to $S$. hexactinia. The presence of an ectopically placed spicule and primary units is 

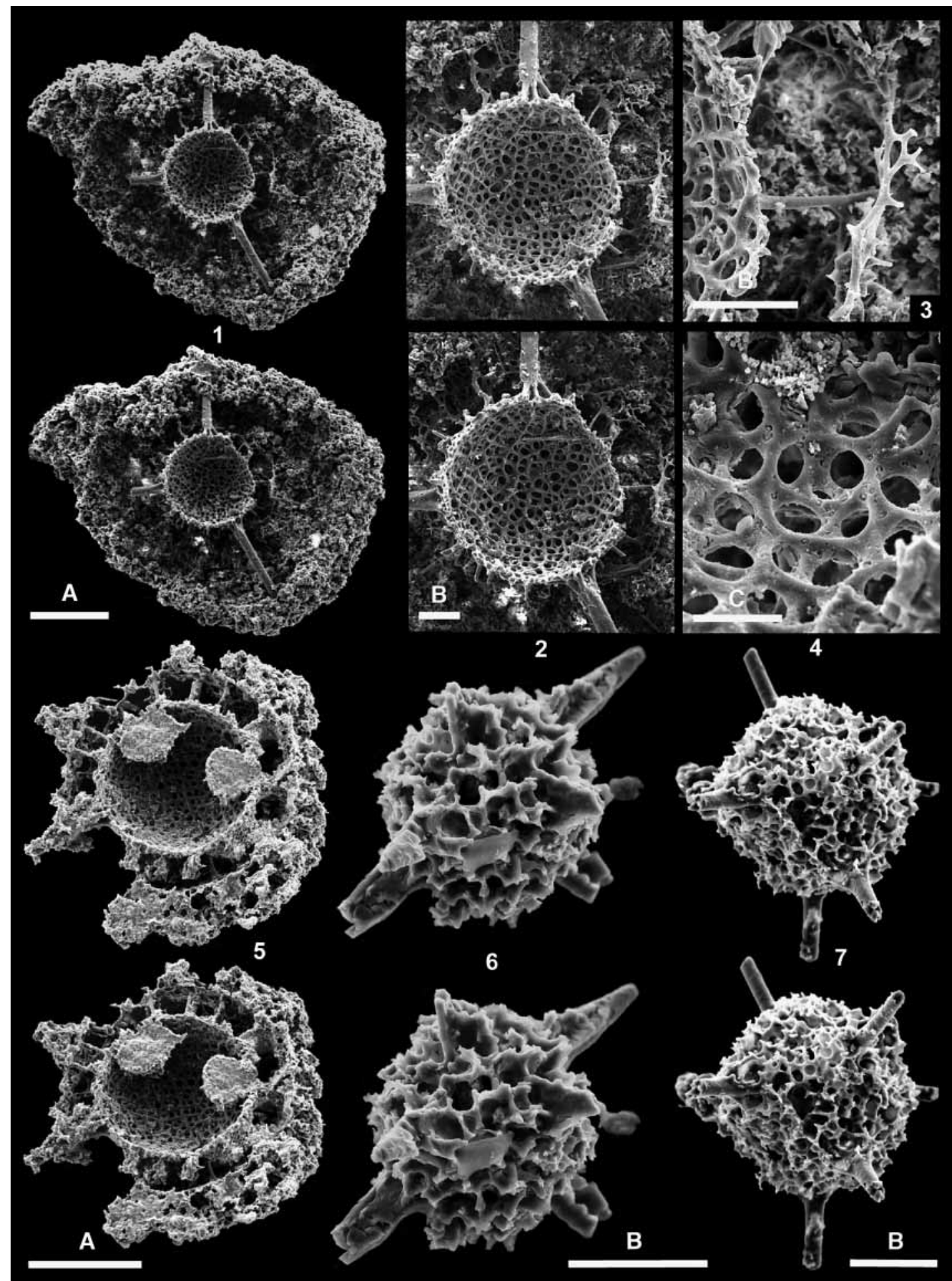

e) 7

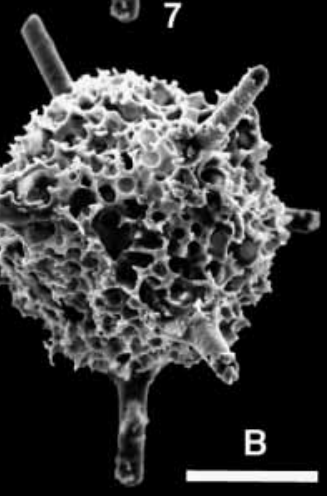

Explanation of Plate 2

All of the specimens (University Museum of Natural History, Oxford) are from the Wenlock Series, Silurian, Herefordshire, England. Figs 1, 2, 5-7 are stereo-pairs. figs 1-5. Inanihella sp.: 1-4, OUM C. $29596-\mathbf{1}$, broken specimen in a 'cocoon', $\times 50 ; \mathbf{2}-\mathbf{4}$, details of lattice and spines, $\times 100, \times 300$, $\times 550$; 5, OUM C.29542, broken specimen in a 'cocoon', $\times 75$. fig 6. Secuicollacta hexactinia. Complete specimen, OUM C. $29597, \times 450$. fig 7. Haplentactinia armista sp. nov. Holotype, complete specimen, OUM C. 29598, × 275. Scales: A, $250 \mu \mathrm{m}$; B, $50 \mu \mathrm{m}$; C, $25 \mu \mathrm{m}$. 
consistent with the diagnosis of Secuicollacta. Although outwardly similar, Parvalanapila fleischerorum MacDonald, 1998 has a denser labyrinthine wall structure. The presence of equatorially arranged spines distinguishes the external morphology from that of Secuicollacta glaebosa MacDonald, 1998.

\section{CONCLUSIONS}

The Wenlock Series Herefordshire Konservat-Lagerstätte has yielded the only radiolarian fauna known from the Silurian of Britain and one of the few Wenlock radiolarian faunas known world-wide. As with most other documented Silurian radiolarian material the Herefordshire fauna is from near-shelf/shelf sediments. The low diversity fauna consists of Inaniguttidae (one new and one congeneric species), Haplentactiniidae (one new species) and Secuicollactidae (one species). It has limited affinities with Silurian radiolarian assemblages of the southern Urals, Canadian Arctic and Alaska. Stratigraphically, the Herefordshire fauna appears transitional between established Silurian radiolarian Long-spined inaniguttid biozones 2 and 3 .

\section{ACKNOWLEDGEMENTS}

This research was funded by the Leverhulme Trust (F/08581/E), the Natural Environment Research Council (GR3/12053) and English Nature. The authors thank Derek Briggs (Yale University) and Eugene MacDonald (St Francis Xavier University) and Paula Noble (University of Nevada) for comments on the manuscript; A. Swift, R. Branson and W. Thornton (University of Leicester) and S. Ziabrev (formerly of The University of Hong Kong) for technical help; T. Hall, J. Sinclair and R. Fenn for general assistance; and the University of Leicester (David J. S.; study leave).

\section{Manuscript received 13 August 2005 Manuscript accepted 21 January 2007}

\section{REFERENCES}

Aitchison, J.C. 1991. Early Silurian radiolarians from the Gospel Oak Shale, Lachlan Fold Belt, New South Wales, Australia. Sixth INTERRAD conference (International Association of Radiolarian Palaeontologists), University of Florence, Italy, Abstracts, 9.

Aitchison, J.C. \& Murchey, B.L. (Eds) 1992. Significance and application of Radiolaria to terrane analysis. Palaeogeography, Palaeoclimatology, Palaeoecology, 96. Elsevier, Amsterdam, 174pp.

Aitchison, J.C., Hada, S., Ireland, T.R. \& Yoshikura, S. 1996. Ages of Silurian radiolarians from the Kurosegawa terrane, southwest Japan constrained by U/Pb SHRIMP data. Journal of Southeast Asian Earth Sciences, 14: 53-70.

Aldridge, R.J., Siveter, David J., Siveter, Derek J., Lane, P.D., Plamer, D. \& Woodcock, N. 2000. British Silurian Stratigraphy. Geological Conservation Review Series, 19. Joint Nature Conservation Committee, Peterborough, 542pp.

Amon, E.O., Braun, A. \& Ivanov, K.S. 1995. Upper Silurian radiolarians from the southern Urals. Geologica et Palaeontologica, 29: 1-17.

Anderson, O.R. 1983. Radiolaria. Springer-Verlag, New York, USA, 365pp.

Bassett, M.G. 1974. Review of the stratigraphy of the Wenlock Series in the Welsh Borderland and South Wales. Palaeontology, 17: 745-777.

Bassett, M.G., Bluck, B.J., Cave, R., Holland, C.H. \& Lawson, J.D. 1992. Silurian. In: Cope, J.C.W., Ingham, J.K. \& Rawson, P.F. (Eds), Atlas of Palaeogeography and Lithofacies. Geological Society, London, Memoirs, 13: 37-56.
Brett, C.E., Boucot, A.J. \& Jones, B. 1993. Absolute depths of Silurian benthic assemblages. Lethaia, 26: 25-40.

Briggs, D.E.G., Siveter, David J. \& Siveter, Derek J. 1996. Softbodied fossils from a Silurian volcaniclastic deposit. Nature, 382: 248-250.

Briggs, D.E.G., Sutton, M.D., Siveter, David J. \& Siveter, Derek J. 2004. A new phyllocarid (Crustacea: Malacostraca) from the Silurian Fossil-Lagerstätte of Herefordshire, UK. Proceedings of the Royal Society of London, Series B, 271: 131-138.

Briggs, D.E.G., Sutton, M.D., Siveter, David J. \& Siveter, Derek J. 2005. Metamorphosis in a Silurian barnacle. Proceedings of the Royal Society, London B, 272: 2365-2369.

Calkins, G.N. 1909. Protozoology. Lea \& Febiger, New York, 349pp.

Deflandre, G. 1953. Radiolaires fossiles. In: Grassé, P. (Ed.), Traité de Zoologie, 1 (2). Masson, Paris, 389-436.

Dumitrica, P., Caridroit, M. \& DeWever, P. 2000. Archaeospicularia, ordre nouveau de radiolaires: une nouvelle étape pour la classification des radiolaires du Paléozoïque inférieur. Comptes rendus de l'Académie des sciences. Série II. Sciences de la terre et des planets, 330 : 563-569.

Ehrenberg, C.G. 1838. Über die Bildung der Kreidefelsen und des Kreidemergel durch unsichtbare Organismen. Abhandlungen Konigliche Akademie der Wissenschaften zu Berlin, 1838: 59-147.

Ehrenberg, C.G. 1875. Fortsetzung der mikrogeologischen Studien als Gesammt-Uebersichtder mikroskopischen Palaontologie gleichartig analysirter Gebirgsarten der Erde, mit specieller Rucksicht auf den Polycystinen-Mergel von Barbados. Konigliche Akademie der Wissenschaften zu Berlin, Abhandlungen, 1875: $1-225$.

Foreman, H.P. 1963. Upper Devonian Radiolaria from the Huron member of the Ohio shale. Micropaleontology, 9: 267-304.

Fortey, R.A. \& Cocks, L.R.M. 2003. Palaeontological evidence bearing on global Ordovician-Silurian reconstructions. Earth Science Reviews, 61: 245-307.

Furutani, H. 1990. Middle Paleozoic radiolarians from Fukuji Area, Gifu Prefecture, central Japan. Journal of Earth Sciences, Nagoya University, 37: 1-56.

Goodbody, Q.H. 1986. Wenlock Palaeoscenidiidae and Entactiniidae (Radiolaria) from the Cape Phillips Formation of the Canadian Arctic Archipelago. Micropaleontology, 32: 129-157.

Gorka, H. 1994. Late Caradoc and early Ludlow Radiolaria from Baltic erratic boulders. Acta Paleontologica Polonica, 39: 169-179.

Hurst, J.M., Hancock, N.J. \& McKerrow, W.S. 1978. Wenlock stratigraphy and palaeogeography of Wales and the Welsh Borderland. Proceedings of the Geologists' Association, 89: 197-226.

Jones, M.K. \& Noble, P.J. in press. Sheinwoodian (uppermost Lower Silurian) Radiolarian from the Cape Phillips Formation, Nunavut, Canada. Micropaleontology, 52.

Kozur, H. \& Mostler, H. 1982. Entactinaria suborder nov., a new radiolarian suborder. Geologische-Palaontologische Mitteilungen Innsbruck, 11: 399-414.

Kurihara, T. \& Sashida, K. 1998. Occurrence and significance of the Late Silurian and Early to Middle Devonian radiolarians from the Kuzuryu Lake district of the Hida Gaien Belt, Fukui Prefecture, central Japan. Journal of the Geological Society of Japan, 104: 845-858.

Li, H.-S. 1994. Middle Silurian radiolarians from Keerhada, Xinjiang. Acta Micropalaeontologica Sinica, 11: 259-272 [in Chinese, with English summary].

MacDonald, E.W. 1998. Llandovery Secuicollactinae and Rotasphaeridae (Radiolaria) from the Cape Phillips Formation, Cornwallis Island, Arctic Canada. Journal of Paleontology, 72: 585-604.

MacDonald, E.W. 1999. Insolitignum n. gen. and Palaeoephippium Goodbody 1986 (Radiolaria) from the Lower Silurian of the Cape Phillips Formation, Arctic Canada. Canadian Journal of Earth Sciences, 36: 2051-2057.

MacDonald, E.W. 2003. Radiolaria from the Lower Silurian of the Cape Phillips Formation, Cornwallis Island, Nunavut, Canada. PhD thesis. Dalhousie University, Halifax, Nova Scotia, 370pp.

MacDonald, E.W. 2004. Palaeoscenidiidae (Radiolaria) from the Lower Silurian of the Cape Phillips Formation, Cornwallis Island, Nunavut, Canada. Journal of Paleontology, 78: 257-274. 
MacDonald, E.W. 2006a. Haplotaeniatumidae and Inaniguttidadae (Radiolaria) from the Lower Silurian of the Cape Phillips Formation, Cornwallis Island, Nunavut, Canada. Journal of Paleontology, 80: 19-37.

MacDonald, E.W. 2006b. A preliminary radiolarian biozonation for the Lower Silurian of the Cape Phillips Formation, Nunavut, Canada. Canadian Journal of Earth Sciences, 43: 205-211.

Maletz, J. \& Reich, M. 1997. Radiolarians and sponge spicules from the Spirograptus turriculatus Zone (Llandovery, Silurian) of the Siljan district, Dalarna (Sweden). Greifswalder Geowissenschaftliche Beiträge, 4: 101-111.

Müller, J. 1858. Über die Thalassicollen, Polycystinen und Acanthometren des Mittelmeeres. Abhandlungen Konigliche Akademie Wissenschaften zu Berlin, 1858: 1-62.

Nazarov, B.B. 1975. Lower and Middle Paleozoic radiolarians of Kazakhstan (methods of investigation, systematics, stratigraphic importance). Transactions of the Academy of Sciences of the USSR, Geological Institute. Izdatelstvo Nauka, Moscow, USSR, [in Russian].

Nazarov, B.B. 1988. Palaeozoic Radiolaria. Practical manual of microfauna of the USSR, 2. Nedra Press, Leningrad, 232pp. [in Russian].

Nazarov, B.B. \& Ormiston, A.R. 1984. Tentative system of Paleozoic Radiolaria. In: Petrushevska, M.G. \& Stepanjants, S.D. (Eds), Morphology, Ecology and Evolution of Radiolaria. Eurorad IV Symposium volume, October 15-19. Akademia NAUK SSSR Ecological Institute, 64-87.

Nazarov, B.B. \& Ormiston, A.R. 1993. New biostratigraphically important Paleozoic Radiolaria of Eurasia and North America. In: Blueford, J.R. \& Murchey, B.L. (Eds), Radiolaria of giant and subgiant fields in Asia. Nazarov Memorial Volume. Micropaleontology Special Publication, 6. American Museum of Natural History, New York, 22-60.

Nazarov, B.B. \& Popov, L.Y. 1980. Stratigraphy and fauna of the siliceous-carbonate sequence of the Ordovician of Kazakhstan (Radiolaria and inarticulate brachiopods). Trudy Geologicheskij Institut Academija Nauk SSSR, 331: 182pp [in Russian].

Noble, P.J. 1994. Silurian radiolarian zonation for the Caballos Novaculite, Marathon Uplift, West Texas. Bulletins of American Paleontology, 106: 1-55.

Noble, P.J. \& Aitchison, J.C. 1995. Status of Ordovician and Silurian radiolarian studies in North America. In: Blome, C.D., Whalen, P.M \& Reed, K.M. (Eds), Siliceous Microfossils. Short Courses in Paleontology. The Paleontological Society, University of Tennessee, Knoxville, 19-30.

Noble, P.J. \& Aitchison, J.C. 2000. Early Paleozoic radiolarian biozonation. Geology, 28: 367-370.

Noble, P.J. \& Maletz, J. 2000. Radiolaria from the Telychian (Llandovery, Early Silurian) of Dalarna, Sweden. Micropaleontology, 46: $265-275$.

Noble, P.J., Ketner, K.B. \& McClelland, W. 1997. Early Silurian radiolaria from northern Nevada, USA. Marine Micropaleontology, 30: $215-223$.

Noble, P.J., Braun, A. \& McClelland, W. 1998. Haplotaeniatum faunas (Radiolaria) from the Llandoverian (Silurian) of Nevada and Germany. Neues Jarbuch für Geologie und Palaeontologie, Mh, 1998: 705-726.

Orr, P.J., Siveter, Derek J., Briggs, D.E.G., Siveter, David J. \& Sutton, M.D. 2000a. A new arthropod from the Silurian KonservatLagerstätte of Herefordshire, England. Proceedings of the Royal Society of London, Series B, 267: 1497-1504.

Orr, P.J., Briggs, D.E.G., Siveter, David J. \& Siveter, Derek J. 2000b. Three-dimensional preservation of a non-mineralized arthropod in concretions in Silurian volcaniclastic rocks from Herefordshire, England. Journal of the Geological Society, London, 157: 173-186.

Orr, P.J., Siveter, David J., Briggs, D.E.G. \& Siveter, Derek J. 2002. Preservation of radiolarians in the Herefordshire KonservatLagerstätte (Wenlock, Silurian), England, and implications for the taphonomy of the biota. In: Wyse Jackson, P.N., Parkes, M.A. \& Wood, R. (Eds), Studies in Palaeozoic palaeontology and biostratigra- phy in honour of Charles Hepworth Holland. Special Papers in Palaeontology, 67: 205-224.

Pickering, K.T. \& Smith, A.G. 1995. Arcs and backarc basins in the early Palaeozoic Iapetus Ocean. The Island Arc, 4: 1-5.

Renz, G.W. 1988. Silurian radiolarians of the genus Ceratoikiscum from the Canadian Arctic. Micropaleontology, 34: 260-267.

Rüst, D. 1892. Beitrage zur Kenntnis der fossilen Radiolarien aus Gesteinen der Trias und der palaeozoischen Schichten. Palaeontographica, 38: 107-179.

Siveter, David J., Sutton, M.D., Briggs, D.E.G. \& Siveter, Derek J. 2003. An ostracode crustacean with soft parts from the Lower Silurian. Science, 302: 1749-1751.

Siveter, Derek J., Sutton, M.D., Briggs, D.E.G. \& Siveter, David J. 2004. A Silurian sea spider. Nature, 431: 978-980.

Siveter, David J., Siveter, Derek J., Sutton, M.D. \& Briggs, D.E.G. 2007. Brood care in a Silurian ostracod. Proceedings of the Royal Society of London, Series B, 274: 465-469.

Stürmer, W. 1952. Zur technique an Graptolithen und Radiolarian in Main-Kiesel-schiefern. Seckenbergiana, 2: 351-355.

Sutton, M.D., Briggs, D.E.G., Siveter, David J. \& Siveter, Derek J. 2001a. An exceptionally preserved vermiform mollusc from the Silurian of England. Nature, 410: 461-463.

Sutton, M.D., Briggs, D.E.G., Siveter, David J. \& Siveter, Derek J. 2001b. Acaenoplax - polychaete or mollusc? Nature, 414: 602

Sutton, M.D., Briggs, D.E.G., Siveter, David J. \& Siveter, Derek J. 2001c. A three-dimensionally preserved fossil polychaete worm from the Silurian of Herefordshire, England. Proceedings of the Royal Society of London, Series B, 268: 2355-2363.

Sutton, M.D., Briggs, D.E.G., Siveter, David J. \& Siveter, Derek J. 2001d. Methodologies for the visualization and reconstruction of three-dimensional fossils from the Silurian Herefordshire Lagerstätte. Palaeontographica Electronica, 4: Available online at http://palaeo-electronica.org/2001_1/s2/issue1_01.htm.

Sutton, M.D., Briggs, D.E.G., Siveter, David J., Siveter, Derek J. \& Orr, P.J. 2002. The arthropod Offacolus kingi (Chelicerata) from the Silurian of Herefordshire, England: computer based morphological reconstructions and phylogenetic affinities. Proceedings of the Royal Society of London, Series B, 269: 1195-1203.

Sutton, M.D., Briggs, D.E.G., Siveter, David J. \& Siveter, Derek J. 2004. Computer reconstruction and analysis of the vermiform mollusc Acaenoplax hayae from the Herefordshire Lagerstätte (Silurian, England), and implications for molluscan phylogeny. Palaeontology, 47: $293-318$.

Sutton, M.D., Briggs, D.E.G., Siveter, David J. \& Siveter, Derek J. 2005a. Silurian brachiopods with soft-tissue preservation. Nature, 436: 1013-1015.

Sutton, M.D., Briggs, D.E.G., Siveter, David J., Siveter, Derek J. \& Gladwell, D.J. 2005b. A starfish with three-dimensionally preserved soft-parts from the Silurian of England. Proceedings of the Royal Society of London, Series B, 272: 1001-1006.

Sutton, M.D., Briggs, D.E.G., Siveter, David J. \& Siveter, Derek J. 2006. Fossilized soft tissues in a Silurian platyceratid gastropod. Proceedings of the Royal Society of London, Series B, 273: 1039-1044.

Umeda, M. 1997. Late Silurian and Early Devonian radiolarians from Konomori area in the Kurosegawa Terrane, Southwest Japan. Chikyu Kagaku, 51: 413-432.

Umeda, M. 1998a. Some Late Silurian characteristic radiolarians from the Yokokurayama Group in the Kurosegawa Terrane, Southwest Japan. Chikyu Kagaku, 52: 203-209.

Umeda, M. 1998b. The Silurian and Devonian Yokokurayama Group of the Kurosegawa Terrane, in the Yokokurayama area, Kochi, Southwest Japan. Journal of the Geological Society of Japan, 104: 365-376.

Umeda, M. 1998c. Upper Silurian-Middle Devonian radiolarian zones of the Yokokurayama and Konomori areas in the Kurosegawa Belt, Southwest Japan. The Island Arc, 7: 637-646.

Umeda, M. \& Suzuki, Y. 2005. Aeronian (Llandovery, Early Silurian) Radiolarians from the Kallholn Formation in Siljan district, Sweden. Micropaleontology, 51: 83-92. 


\section{Silurian Radiolaria of England}

Wakamatsu, H., Sugiyama, K. \& Furutani, H. 1990. Silurian and Devonian radiolarians from the Kurosegawa Tectonic Zone, southwest Japan. Journal of Earth Sciences, Nagoya University, 37: 157-192.
Won, M-Z., Blodgett, R.B. \& Nestor, V. 2002. Llandoverian (Early Silurian) radiolarians from the Road River Formation of east-central Alaska and the new family Haplotaeniatumidae. Journal of Paleontology, 76: 941-964. 